\title{
Mário de Andrade: Outlaw ou Au-dessus de la Mêtée?
}

\author{
Valter Cesar Pinheiro \\ Universidade Federal de Sergipe
}

\section{Resumo}

Este artigo intenta compreender, a partir da leitura de ensaios escritos nos anos 1930, o posicionamento de Mário de Andrade quanto a uma questão ainda atual: quais são o papel e a função social do artista e do intelectual? São nos textos daquela fase - mais do que nos da década seguinte - que se fixam alguns dos conceitos mais caros ao autor, como "consciência artística", "artesanato" e "traição", o que justifica sua retomada.

\section{Abstract}

This article seeks to understand, through a reading of essays written in the 1930's, Mário de Andrade's position regarding an issue still relevant today: what are the role and the social function of the artist and the intellectual? The texts from that period-more than those from the following decade-establish some of the author's most cherished concepts, such as "artistic consciousness", "craftsmanship" and "betrayal”, justifying their reconsideration here.

\section{Palavras-chave}

Mário de Andrade, Modernismo, intelectual, poesia, engajamento.

\section{Keywords}

Mário de Andrade, Modernism, intellectual, poetry, engagement. 
"Eu sou trezentos": é com este poema - cujo verso inicial tornar-se-ia célebre - que Mário de Andrade abre Remate de males, publicado em 1930. Não por acaso, o verso intitula a recentíssima biografia do autor de Macunaíma composta por Eduardo Jardim, lançada, por ocasião da lembrança do septuagésimo aniversário de morte do romancista paulistano, em fevereiro deste ano. ${ }^{1}$

Romancista? Mário de Andrade exemplifica, talvez melhor do que ninguém, a figura do intelectual polígrafo: poeta, crítico literário, teórico da arte, musicólogo, jornalista, professor, folclorista, "agitador cultural": poucos foram os domínios no campo das artes plásticas, da literatura ou da música com os quais Mário não se tenha envolvido direta e profundamente e, ressalte-se, deixado um legado de indubitável importância, seja ele ensaístico, artístico, ou político, pois esteve à frente do Departamento de Cultura da Cidade de São Paulo (o primeiro do gênero no país).

O propósito deste texto é trazer à ribalta a seguinte questão: qual seria, para Mário de Andrade, o papel do artista e do intelectual no mundo contemporâneo? Qual seria sua função social? Com o propósito de entender sua posição em relação a essas questões, serão retomados, aqui, alguns de seus ensaios. O primeiro deles, "A poesia em 1930", foi publicado em 1931, e o último, “A volta do condor", em 1941. Dos artigos escolhidos, três foram escritos entre os anos de 1931 e 1932 e cinco entre 1938 e 1941 . Neste interregno, entre 1935 e 1937, Mário, como assinalado, dirigiu o Departamento de Cultura da Cidade de São Paulo, o que justifica, em parte, as mudanças de posicionamento do autor. A opção por textos escritos durante a década de 1930 não é aleatória: na história da cultura brasileira, a preocupação com o papel social do intelectual e do artista nunca se fez tão urgente quanto naquele momento histórico (essa matéria, aliás, estava no âmago do projeto modernista, entabulado na década anterior), o que justifica a importância da retomada dos artigos que serviram de base aos grandes ensaios escritos na década de 1940 (nos quais aparecem de forma sistemática conceitos desenvolvidos no decênio precedente, como "consciência artística", "artesanato" e "traição", entre outros).

João Luiz Lafetá demarca, em 1930: a crítica e o Modernismo, ${ }^{2}$ duas fases na obra crítica de Mário de Andrade: na primeira, dos anos vinte, prevaleceria o aspecto estético sobre o ideológico, e na segunda, que se inicia na década de trinta e se estende até o final da vida do escritor, distinguir-se-ia o aspecto ideológico. A dimensão estética não é, todavia, negligenciada nos textos dos anos trinta: é sob a perspectiva da forma que o autor de Amar, verbo intransitivo teria tratado da intricada questão do engajamento artístico.

Essa perspectiva pretende diferenciar a função da arte da de outras formas de expressão (intelectuais, mas não necessariamente artísticas). Mário de Andrade fazia essa discriminação, reiterando os perigos aos quais ficavam sujeitos os que se propunham obstinadamente a apenas fazer "arte engajada". No entanto, a maior parte dos estudiosos refere-se em sua crítica basicamente aos escritos da década de 1940, nos quais justamente a questão do engajamento aparece de forma mais contraditória. Eis porque optei por retomar artigos escritos na década de 1930, anteriores, portanto, aos conhecidos ensaios dos anos quarenta: são nesses primeiros textos que a delicada questão do papel do artista e do intelectual é tratada de forma menos vacilante, e o conjunto pode, por conseguinte, ajudar a melhor esclarecer a posição de Mário de Andrade em relação a essa discussão tão importante.

\section{"A poesia em 1930"3}

O ensaio tem por objetivo analisar as quatro obras que seriam, para Mário de Andrade, os principais livros de poesia daquele ano: Alguma poesia, de Carlos Drummond de Andrade; Libertinagem, de Manuel

\footnotetext{
${ }^{1}$ JARDIM, Eduardo. Eu sou trezentos: Mário de Andrade vida e obra. Rio de Janeiro: Edições de Janeiro, 2015.

${ }^{2}$ LAFETÁ, João Luiz. 1930: a crítica e o Modernismo. $2^{\mathrm{a}}$ edição. São Paulo: Duas Cidades; Editora 34, 2000.

${ }^{3}$ In: ANDRADE, Mário de. Aspectos da literatura brasileira. 6a edição. São Paulo: Martins Editora, 1978, p. 27-45. Artigo publicado originalmente na Revista Nova (ano I, nº1, 15/03/1931, p. 102-123).
} 
Bandeira; Pássaro cego, de Augusto Frederico Schmidt; e Poemas, de Murilo Mendes. Mário exalta o fato de que essas obras eram fruto de artistas maduros, conscientes do fazer poético. "A poesia é um grande mal humano", diz ele. "Ela [a poesia] só tem direito de existir como fatalidade que é, mas esta fatalidade apenas se prova a si mesma depois de passadas as inconveniências da aurora"4 Inexperiência de vida, inexperiência estética: o mau uso que os jovens faziam do verso livre (que resultava em "frases fantasiosamente enfileiradas", em "uma desritmização boba" e em "uma falta pavorosa de contribuição pessoal") era a constatação mais visível da "envolumação precipitada" - erro grave em que incidiam os jovens autores. Mário redefine o conceito de verso livre ("aquisição de ritmos pessoais"), opondo-o ao "encanto socializador" do verso medido. Sendo o verso livre "uma vitória do individualismo", o seu uso por parte daqueles que não têm experiência de vida nem a técnica necessária para a composição da obra de arte levaria ao triste quadro que se via naquele momento: a publicação daquele "monturinho sapeca de livros de moços, coisa inútil”".

Mário de Andrade fundamenta sua leitura em três elementos: o estético (linguagem), o psicológico e o sociológico; os dois últimos a serviço do primeiro, o que mantém a linguagem como questão central de sua análise. Ao abordar Libertinagem, destaca a importância do individualismo na poética de Manuel Bandeira (que se concretiza formalmente por meio de um ritmo "áspero", "anguloso", semelhante a seu autor). E, diz Mário, são justamente os poemas marcados por esse individualismo os mais significativos na obra do poeta recifense, porque mais universais: “As melhores obras do poeta (...) são as poesias em que por mais pessoais que sejam assuntos e detalhes, mais o poeta se despersonaliza, mais é toda a gente e menos é caracteristicamente ritmado".

O individualismo seria, igualmente, a maior qualidade dos Poemas de Murilo Mendes: "E o resultado importantíssimo desse apenas aparente individualismo, que na realidade é antes um excesso do indivíduo no que ele tem de mais complexo, (...) é que em vez de pormenorização pessoal, a obra dele é profundamente humana e genérica", embora este individualismo se distinga daquele apontado em Manuel Bandeira no plano da realização poética. Mário aponta a falta dessa característica como o maior defeito dentre os "32 cacoetes" que compõem a poética de Augusto Frederico Schmidt, e esta ausência, observa o crítico, manifestar-se-ia tanto no plano do conteúdo (na escolha de temas universais, como o Amor, Deus ou o Mar) quanto no plano da forma (cada vez mais próxima do verso metrificado).

É importante ressaltar que isso não é uma condenação do emprego do verso medido. O uso do verso livre não assegura a qualidade do poema, assim como o emprego do verso medido não é sinônimo de atraso ou de poema ruim. Volta-se à questão do fazer poético: o conhecimento do artesanato e da virtuosidade e a solução pessoal que o poeta imprimirá à sua obra são os elementos que definirão a qualidade e o valor de um poema, não a forma tomada isoladamente do conjunto.

Desse modo, chega-se à seguinte equação: quanto maiores forem os traços individuais de um poema (nos níveis da forma e do conteúdo, sendo as escolhas permeadas pela consciência artística do poeta), maior será sua força, maior será seu efeito na sensibilidade do leitor, maior será sua universalidade. Por outro lado, quanto menos marcas houver do indivíduo criador em sua poética (também nos planos da elaboração formal e do assunto), menor será a profundidade de sua obra. Nesse caso, o poeta daria ao leitor, quando muito, provas do seu virtuosismo, sem nenhuma contribuição individual: estaria fazendo arte conformista.

\footnotetext{
${ }^{4}$ Mais tarde, em 1939, Mário de Andrade dirá: “A poesia nasce de uma dor" ("Do conformismo", publicado no Diário de Notícias do Rio de Janeiro em 30/04/1939. Esse texto faz parte do volume Vida literária (ANDRADE, Mário de. Vida literária. [Pesquisa, estabelecimento de texto, introdução e notas por Sonia Sachs]. São Paulo: Hucitec; Edusp, 1993, p. 39-46.)
} 
A consciência artística que Mário tanto apregoa seria a maior qualidade de Drummond: sua poética "tem mesmo (...) um compromisso claro entre o verso livre e a metrificação. (...) $\mathrm{O}$ emprego da metrificação provém, nele, de uma vontade íntima de se aniquilar, de se esconder”. O verso medido de Drummond não é, pois, um defeito, mas uma grande qualidade: ele responde ao desejo do poeta de obliterar (em alguns momentos) o seu "eu". Adotando o verso medido, o poeta mascara no nível da forma o "eu lírico", dando ao leitor prova de sua grande competência artística.

Mário, no entanto, não consegue resolver a contradição que se estabelece entre a necessidade de engajamento do criador (no caso, o poeta) e o necessário caráter individual e livre da obra artística (a poesia). Defende o caráter específico desta última, mas parece não reconhecer a especificidade do poeta em relação a outros artistas e intelectuais: ao referir-se à "inutilidade pessoal" do poeta e às "exigências da vida social contemporânea", indica a necessidade de participação social dos poetas (e, de quebra, abre a discussão relativa à profissionalização do escritor e do atrelamento do "escritorfuncionário público" ao aparelho de Estado, questão que só ganhará destaque dez anos depois). Por outro lado, não aceita que a poesia se submeta a qualquer tipo de compromisso: "Porque, vamos e venhamos, a Poesia não pode permanecer neste compromisso de facilidades sentimentaizinhas e didáticas em que quase exclusivamente se confina entre nós".

Um assunto desta complexidade num momento delicado como aquele (pós-crash de 1929 e com a Revolução de 1930 em curso) não poderia mesmo fornecer a quem se dispusesse a discuti-lo uma solução definitiva e coerente. Mário de Andrade tenta harmonizar conceitos aparentemente antagônicos: parece distinguir "conformismo" de "engajamento" - o primeiro, mais atrelado ao fazer poético e à consciência artística do poeta; o segundo, relacionado à participação do criador na sociedade, tomando partido, defendendo uma causa - e insiste na diferença entre prosa e poesia - que se dá não no plano da forma, mas em seu fundo: uma, de cunho intelectual, "desenvolve noções", "associa ideias"; outra, "livre da inteligência", submete-se às impulsões líricas do criador. Sua reflexão, entretanto, para neste ponto: Mário reconhece a necessidade de engajamento ("exigências da vida social contemporânea"), mas não sabe exatamente de que forma o poeta pode "descer à rua" sem trair o caráter específico da poesia.

\section{"Intelectual I-II"5}

Publicados originalmente no Diário Nacional ${ }^{6}$ de São Paulo, esses artigos têm por eixo a discussão do papel do intelectual na sociedade contemporânea e pretendem mostrar quão alienados são os intelectuais brasileiros (condição que nem mesmo as conquistas do Modernismo haviam conseguido mudar). Assim começa o primeiro artigo da série, "Intelectual I":

Aqui neste paraíso de inconsciência que é o Brasil, no geral os grandes fatos sociais passam sem grande repercussão, em branca nuvem. Aquela imagem excelente de Olegário Mariano, do homem brasileiro tendo por único incômodo da sua existência a saudade, da qual ele se vinga "tocando viola de papo pro ar", não é apenas o retrato do homem brasileiro comum, do burguês, do proletário, ou do sertanejo: é u'a imagem que se dilata espantosamente, e vai servir até como reprodução do homem culto brasileiro, do chamado "intelectual".?

\footnotetext{
5 "Intelectual I", "Intelectual II". In: ANDRADE, Mário de. Taxi e Crônicas no Diário Nacional. [Estabelecimento de texto, introdução e notas de Telê Porto Ancona Lopez]. São Paulo: Duas Cidades; Secretaria da Cultura, Ciência e Tecnologia, 1976. Taxi e crônicas no Diário Nacional, p. 515-520.

6 "Intelectual I" em 10/04/1932 e "Intelectual II" em 17/04/1932.

${ }^{7}$ ANDRADE, Taxi e Crônicas no Diário Nacional, op. cit., p.515.
} 
Mário cita como exemplos da afirmação que faz a pouca (ou nenhuma) repercussão que houve no Brasil de acontecimentos "infamantes" ocorridos no estrangeiro naquele período, como a revolução comunista na China. "Os intelectuais brasileiros não protestaram contra nada", lamenta Mário, "nada se inculpou, não se acusou coisíssima nenhuma".

Infelizmente, nem mesmo as conquistas do Modernismo foram capazes de mudar esse estado de coisas:

Com o "modernismo" mudou-se de maneiras de versejar, se espevitou mais um bocado o jeito de dizer, se enfeitou a nossa escrita de brasileirismos vocabulares, grande mudança! $\mathrm{Na}$ verdade o intelectual brasileiro continua tocandinho na viola o toque rasgado da sua pasmosa inércia humana. ${ }^{8}$

Para Mário, o "estado de consciência" do intelectual brasileiro não sofrera nenhuma alteração desde os tempos dos "fazedores de Academias celestiais", como Machado de Assis, Joaquim Nabuco ou José Veríssimo, que, como "aqueles rendeiros [que vivem] numa praia deserta do norte", se afastaram completamente da realidade em que viviam. $\mathrm{O}$ que marca os intelectuais daquele período (e igualmente marcaria os intelectuais de seu tempo) é a total falta de "paixão pela vida", a "nenhuma generosidade intelectual". E, continua Mário, a falta de consciência dos intelectuais se refletia na má leitura de obras como Os sertões, de Euclides da Cunha ("Toda a gente admira o esplendor da obra criada e se esquece da seca”), e La trahison des clercs, de Julien Benda:

E nisso nós estamos inda agora. Enternecimentos estéticos, cajuadas de recolhimento reflexivo, torre-de-marfim, nos vingando da saudade. O famoso Trahison des clercs também fez alguma comoção nos meios intelectuais modernos do Brasil: mas se no mundo ele teve como esplêndido, inesperado e humano ofício tornar os traidores mais conscientes e decididos da sua traição, parece que entre nós serviu só pra que cada qual aceitasse a tese falada de Benda, e ficasse inda mais gratuito, mais trovador da "arte pela arte", ou do pensamento pelo pensamento. ${ }^{9}$

Editada em 1927, La trahison des clercs trata da questão do engajamento na arte, ou, em outros termos, da supremacia, no pensamento e nos valores do intelectual moderno, do temporal sobre o atemporal. Inicialmente, Benda faz a distinção entre o que ele denomina "leigo" e "clérigo":

je n'ai considéré que des masses, bourgeoises ou populaires, des rois, des ministres, des chefs politiques, soit cette partie de l'espèce humaine que j'appellerai laïque, dont toute la fonction, par essence, consiste en la poursuite d'intérêts temporels et qui ne fait, en somme, que donner ce qu'on devait attendre d'elle en se montrant de plus en plus uniquement et systématiquement réaliste. (...) je veux parler de cette classe d'hommes que j'appellerai les clercs, en désignant sous ce nom tous ceux dont l'activité, par essence, ne poursuit pas de fins pratiques, mais qui, demandant leur joie à l'exercice de l'art ou de la science ou de la spéculation métaphysique, bref à la possession d'un bien non temporel, disent en quelque manière: "Mon royaume n'est pas de ce monde."10

O "intelectual-clérigo" deve ter por valores principais a Justiça, a Verdade e a Razão, valores universais, imutáveis, que estão acima de qualquer interesse temporal ou circunstancial, acima de qualquer

\footnotetext{
${ }^{8}$ Ibidem, p.516.

${ }^{9}$ Ibidem.

${ }^{10}$ BENDA, Julien. La trahison des clercs. Paris: Bernard Grasset, 1990, p.131-132. "Eu considerei [nos capítulos precedentes] apenas as massas, burguesas ou populares, reis, ministros, chefes políticos, ou seja, esta parte da espécie humana que chamarei leiga, cuja única função, essencialmente, consiste na busca de interesses temporais, e que, em suma, não faz senão dar o que se deveria esperar dela, mostrando-se cada vez mais única e sistematicamente realista. Quero [agora] falar desta categoria de homens que denominarei clérigos, designando sob este nome todos aqueles cuja atividade, fundamentalmente, não almeja fins práticos, mas que, postulando sua alegria no exercício da arte ou da ciência ou da especulação metafísica, ou seja, na posse de um bem não temporal, parecem nos dizer: 'Meu reino não é deste mundo"'.
} 
objetivo imediato. São esses os valores pelos quais o intelectual deve lutar, mantendo-se distante das discussões políticas que visam a interesses práticos:

Enfin je voudrais encore préciser ma pensée sur un point et dire que le clerc ne me paraît manquer à sa fonction en descendant sur la place publique que s'il y descend (...) pour y faire triompher une passion réaliste de classe, de race ou de nation. (...) Au reste, il existe un critérium très sûr pour savoir si le clerc qui agit publiquement le fait conformément à son office: il est immédiatement honni par le laïc, dont il gêne l'intérêt (Socrate, Jésus). On peut dire à l'avance que le clerc loué par des séculiers est traître à sa fonction. ${ }^{11}$

E a consequência da intromissão dos intelectuais nos assuntos de ordem política e econômica era o fato de que eles não sabiam distinguir suas "paixões políticas" do caráter universal e atemporal do seu trabalho, que é, por definição, desinteressado.

Segundo Mário, diferentemente do que se passara no resto do mundo, a tese de Benda foi bem aceita por nossos intelectuais ${ }^{12}$ : ela viria ao encontro da gratuidade e da falta de consciência que caracterizavam nossa classe culta. E, nesse momento, Mário de Andrade, mediante uma comparação que se tornará famosa, define o intelectual e distingue a "verdade" pela qual este deve lutar da "Verdade" defendida por Julien Benda:

Na realidade, a situação pra quem queira se tornar um intelectual legítimo é terrível. Hoje mais que nunca o intelectual ideal é o protótipo do fora-da-lei, fora de qualquer lei. O intelectual é o ser livre em busca da verdade. A verdade é a paixão dele. E de fato o ser humano socializado, as sociedades, as nações, nada têm que ver com a Verdade. Elas se explicam, ou melhor, se justificam, não pela Verdade, mas por um sem-número de verdades locais, episódicas, temporárias, que, estas, são frutos de ideologias e de idealizações. O intelectual pode bem, e deverá sempre, se pôr a serviço duma dessas ideologias, duma dessas verdades temporárias. Mas por isso mesmo que é um cultivado, e um ser livre, por mais que minta em proveito da verdade temporária que defende, nada no mundo o impedirá de ver, de recolher e reconhecer a Verdade da miséria do mundo. Da miséria dos homens. O intelectual verdadeiro, por tudo isso, sempre há de ser um homem revoltado e um revolucionário, pessimista, cético e cínico: fora-da-lei. ${ }^{13}$

O que está em discussão é a função social do intelectual, e, na passagem que se acaba de ler, pode-se observar que Mário de Andrade se opõe brutalmente à definição do intelectual como "clérigo moderno" proposta por Julien Benda: para o escritor paulistano, o intelectual deve pôr a sua liberdade e capacidade de reflexão a serviço da sociedade. Seu discurso, consequentemente, seria inevitavelmente impregnado de um forte tom ideológico, visto que a escolha de valores é, por natureza, ideológica.

“Intelectual I-II”, escritos em 1932, pouco lembram “A poesia em 1930”, publicado no ano anterior. Não há, nestes textos, as contradições destacadas no artigo de 1931. Não se pode perder de vista, entretanto, que, nas crônicas de 1932, Mário de Andrade discute a função do intelectual tout court, sem distinguir,

\footnotetext{
${ }^{11}$ Ibidem, p.136. "Eu gostaria enfim de explicitar meu pensamento quanto a isso e dizer que o clérigo não me parecer faltar à sua função descendo à praça pública senão quando o faz com o intuito de ali fazer triunfar uma paixão realista de classe, de raça ou de nação. No mais, existe um critério muito seguro para saber se o clérigo que age publicamente o faz conforme o seu ofício: ele é imediatamente vilipendiado pelo leigo, cujos interesses ele perturba. Pode-se dizer que o clérigo enaltecido por seculares é traidor de sua função."

${ }^{12}$ A recepção da obra de Julien Benda no Brasil merece um estudo à parte. Sabe-se que outros intelectuais compartilhavam das ideias de Mário de Andrade, como Sérgio Milliet, que, em 1932, afiançou: "Não somos daqueles que, com Julien Benda, condenam, por traição, os intelectuais que entram na 'mêlée'. Muito pelo contrário, consideramos impossível, na nossa época, não ser também o escritor um vigoroso combatente, um defensor de 'sua verdade' ou da verdade coletiva que lhe pareça mais 'verdadeira"' (apud CAMPOS, Regina Salgado. Ceticismo e responsabilidade: Gide e Montaigne na obra crítica de Sérgio Milliet. São Paulo: Annablume, 1996, p.90).
}

${ }^{13}$ ANDRADE, Taxi e Crônicas no Diário Nacional, op. cit., p.516. 
no âmbito desse conceito tão vasto, as suas variantes (como, por exemplo, a distinção entre intelectual e artista), o que pode fazer com que se acredite que as contradições de "A poesia em 1930" tivessem sido superadas. A leitura de outros textos do período revela, contudo, que o paradoxo permanece.

\section{"Luís Aranha ou a poesia preparatoriana"14}

Luís Aranha assume, para Mário de Andrade, um papel paradigmático: a atitude que tomara-abandonando a poesia e optando pelo silêncio - seria uma das soluções possíveis ao impasse a que a poesia moderna chegara: a outra seria a transformação completa da concepção de arte, aliada a uma nova consciência, por parte do criador, de sua função social:

O fenômeno realmente importante e decisivo do nosso realismo psicológico foi a fixação consciente do conceito de intelectual. Está claro que este, como os outros, não são fenômenos peculiares ao Brasil. Apenas se tornaram nossos também. Nós hoje nos debatemos sofridamente ante os problemas do homem e da sociedade, com uma consciência, com um desejo de se solucionar, de conquistar finalidade, com um desespero pela posição de fora-dalei inerente ao intelectual de verdade que jamais os artistas do passado brasileiro não tiveram. Basta conceber, por tudo o que nos deixaram de obras, de confissões, de vida, como foram fáceis de adaptabilidade, inconscientes de seus problemas individuais e humanos, um poeta social pragmatizado como Castro Alves, ou um au-dessus de la mêlée tão irredutível como Machado de Assis, pra verificar que o problema do intelectual só veio perturbar a criação do artista brasileiro na época atual. Hoje estamos preocupados em voltar às nascentes de nós mesmos e da arte. Surgem os traidores dissolutos, convictamente injustos, socializados, revertendo tudo à sua fé católica ou à sua fé comunista. Surgiu o pragmatismo estético que nem um Sílvio Romero foi capaz de ter. Em arte surgem os diversos primitivismos, os cubismos, os sobrerealismos, etc. Outros, menos capazes das heroicidades dessas traições, vivem num dualismo acomodatício, buscando seccionar a obra em partes nítidas, uma autoritária, e utilitária, outra livre e pessoal, como Antônio de Alcântara Machado, eu, o caso curioso de Paulo Prado, cuja parte livre não se realiza em obras impressas, mas na sua atuação nos meios artísticos de São Paulo e do Rio. Outros aceitam a insolubilidade do intelectual com ferócia irredutível, como Manuel Bandeira, Augusto Meyer, Carlos Drummond de Andrade. Estes ainda são poetas, fazem poesias, suas obras derivam de seus amores, criam amor; porém os que fazem a prosa dos ensaios e aspiram conservar a insolubilidade do intelectual e permanecer au-dessus de la mêlée, esses irritantemente confrangem as suas verdades a uma discrição invertebrada, que nem sempre consegue ocultar o que pensam e aspiram. Serão talvez os que sofrem mais, por isso mesmo que mais irresolutos em sofrer. E na certa que se enxergam enormemente confundidos com o atual impossível diletantismo. Enfim todos nós estamos conscientes da nossa amarga posição de intelectuais, e movidos pelos fantasmas que nascem desse medo. Uma situação maldita. ${ }^{15}$

Mário de Andrade estabelece como maior conquista do nosso realismo psicológico a fixação do conceito de intelectual, fenômeno que se dá, aliás, em escala planetária, como se havia ressaltado anteriormente. Retomando a comparação feita na crônica "Intelectual I", aproxima a figura do intelectual da do fora-da-lei, sem, entretanto, guardar o tom panfletário daquele texto. No mais, constata-se que "intelectual" e "artista" continuam a ser intercambiáveis, e isso fica bem evidente na primeira metade do trecho supracitado. A contradição, entretanto, estava presente, originando afirmações como esta: "O problema do intelectual só veio perturbar a criação do artista brasileiro na época atual".

\footnotetext{
${ }^{14}$ Revista Nova, ano II, n², 15/09/1932, p. 292-329. In: ANDRADE, Aspectos da literatura brasileira, op. cit., p. 47-87.

${ }^{15}$ Ibidem, p.49-50.
} 
Mário divide os intelectuais brasileiros em três grandes grupos: o dos "traidores dissolutos", o dos que "vivem num dualismo acomodatício" (no qual se insere) e aquele que defende "a insolubilidade do intelectual com ferócia irredutível". O primeiro grupo é composto por aqueles que fizeram de sua arte um instrumento de ação prática, "revertendo tudo à sua fé católica ou à sua fé comunista". Ao chamá-los de "traidores", Mário de Andrade não apenas se apropria do termo empregado por Benda, mas - fato mais importante - utiliza-o com o mesmo sentido. A crítica explicitamente aberta contra as ideias de Benda discorrida nas crônicas do Diário Nacional não encontra eco aqui, talvez porque, naquele momento, não estivesse em questão a criação artística, que implica, para o autor de Pauliceia desvairada, na liberdade e na autonomia absolutas do artista.

No segundo grupo encontram-se todos os que dividem a sua obra em dois eixos: o pragmático (que, para Mário de Andrade, era forçosamente autoritário) e o pessoal (livre). Essa cisão mostra o quanto era difícil para Mário vislumbrar uma saída que conciliasse liberdade criadora e engajamento social. A solução adotada, fácil (daí o termo "dualismo acomodatício"), era dividir a obra em duas partes distintas: a engajada e a criadora, o que lhe causa um enorme constrangimento, como o tom do seu discurso deixa transparecer.

Finalmente, Mário aponta o terceiro grupo, composto pelos que defendem com ardor a autonomia do intelectual. Os que se mantêm poetas ainda conseguem, em virtude do caráter da obra de arte que criam, manter-se au-dessus de la mêlée, condição que perdem no momento em que passam a produzir também prosa ensaística: essa sempre denotaria, por maior que fosse o esforço contrário, suas verdades, seus valores, suas aspirações. Mário fala de "sofrimento" e "confusão", consequência direta do "impossível diletantismo" em que ainda se viam confinados muitos dos intelectuais daquele período, retomando, de outra maneira, o que dissera no ano anterior em seu ensaio “A poesia em 1930": “O meio-termo [obra engajada/ obra livre] está se tornando cada vez mais inaceitável". É o embate "estético" versus "ideológico" atingindo o seu ponto mais alto.

E assim concluo as observações a respeito desse artigo: Mário de Andrade é consciente do impasse no qual se encontra o intelectual e de todas as contradições que essa situação encerra, mas não consegue encontrar uma saída que concilie sua concepção de poesia à necessidade de engajamento que o momento exige. Daí sua "amarga posição", sua "situação maldita". Num momento de maior lucidez, reconhece a importância da proposta de Benda, sem, contudo, abraçá-la: aceita a acusação de "traidor" contra aquele que submete sua arte a uma verdade (em minúscula) temporária, mas sente-se constrangido em defender ao intelectual a sua "torre de marfim", a sua "janelinha de ouro e prata".

“O artista e o artesão"16

Seis anos separam "Luiz Aranha ou a poesia preparatoriana" do ensaio "O artista e o artesão", concebido como aula inaugural dos cursos de Filosofia e História da Arte, ministrados no Instituto de Artes da Universidade do Distrito Federal. O aparente "silêncio" que marca o interregno entre esses textos corresponde ao período de maior atuação política de Mário de Andrade: de 1935 a 1937, o escritor dirigiu o Departamento de Cultura da Prefeitura de São Paulo. A preocupação com o fazer artístico e com a aquisição de uma consciência artística é o eixo que norteia esse ensaio, que marca um grande avanço nas formulações mariodeandradianas. Nele não há a fusão de conceitos como "intelectual" e "artista". O objetivo deste estudo é esclarecer termos até então confusos, como "artesanato" e "técnica", bem como definir a função do artista (e da obra de arte) na sociedade contemporânea.

${ }^{16}$ ANDRADE, Mário de. “O artista e o artesão”. In: O baile das quatro artes. São Paulo: Martins Editora, 1943, p.9-33. 
Partindo da afirmação de que “em arte, o que existe de principal é a obra de arte”, Mário de Andrade esmera-se em precisar as condições necessárias para que o artista possa fazer, com sua arte, grandes obras. Para isso concorreriam três elementos fundamentais: o artesanato, a virtuosidade e a solução pessoal do artista. Os dois primeiros seriam ensináveis - o artesanato, que corresponde ao "aprendizado do material com que se faz a obra de arte", e a virtuosidade, que seria o conhecimento das técnicas tradicionais -, diferentemente do terceiro aspecto - a solução pessoal. Fazendo uma síntese da história da arte, Mário chega às ideias de "beleza" e de "individualismo" e estabelece entre elas um paralelo: o "belo" é tão inerente à obra de arte quanto o "individual" ao artista. O grande impasse no qual a arte contemporânea chegara decorria do fato de que a exacerbação dessas ideias fizera com que a arte perdesse o seu caráter utilitário e social: "a inflação do individualismo, a inflação da estética experimental, a inflação do psicologismo, desnortearam o verdadeiro objeto da arte". "Hoje", continua Mário, "o objeto da arte não é mais a obra de arte, mas o artista. E não poderá haver maior engano".

Para superar esse estado de coisas, é fundamental que o artista adquira uma "severa consciência artística que o... moralize. (...) Só que esta severa atitude, antes de mais nada humana, é que deve na realidade orientar e coordenar a criação". E essa consciência artística implicaria "uma nova atitude diante da arte, diante da vida": em outros termos, Mário propõe ao criador que tenha uma "atitude estética" diante da realidade. Assim, retoma o que havia delineado, de forma ainda difusa, em "A poesia em 1930": o engajamento (no sentido de participação social) do artista deve dar-se via obra de arte, no que ela tem de mais específico: sua realização formal. Viu-se que a contradição que se configura no ensaio de 1931 é decorrente da impossibilidade de conciliação entre o caráter individual inerente a certas formas de criação artística (no caso, a poesia) e "as exigências da vida social contemporânea", que demandam um maior engajamento do intelectual e do artista nas questões que envolvem o país e o mundo. Nesse sentido, a consciência artística (que permearia a solução pessoal do criador) aparece como uma tentativa de superação daquela contradição. Desse modo, é atribuído ao experimentalismo e à pesquisa estética - frutos da atitude do artista diante de sua realidade - um sentido social até então inimaginável. As ideias apresentadas nesse artigo são retomadas nos ensaios críticos escritos por Mário de Andrade naquele período. Nesses estudos reaparecem conceitos (como "artesanato" e "técnica") e valores (como a superioridade da obra de arte em relação ao artista) que dão a tônica de "O artista e o artesão". Por isso, propõe-se uma breve leitura dos seguintes textos: "Machado de Assis", "Belo, forte, jovem”, "A poesia em pânico" e "A volta do condor".

Em "Machado de Assis"17, ensaio de 1939, sobressaem as qualidades do autor de Dom Casmurro. Quanto às críticas anteriores (baseadas numa interpretação da personalidade e da visão de mundo de Machado, ser "extremante individualista", "sem generosidade" e "au-dessus de la mêlée"), se não desaparecem totalmente, são, ao menos, bastante atenuadas. Essa mudança não significa que Mário tenha reconsiderado seu ponto de vista sobre o Machado de Assis indivíduo, ser social. O que se dá é uma valorização do Machado artista, perfeito conhecedor de seu ofício.

Como arte, ele foi o maior artesão que já tivemos. E esta é a sua formidável vitória e maior lição. Ele vence, ele domina tudo, pelo artista incomparável que soube ser. Tomando a sério a sua arte, Machado de Assis se aplicou em conhecê-la com uma técnica maravilhosa. É impossível se imaginar maior domínio do métier. Fonte de exemplo, fonte de experiência, treino indispensável, dador fecundo de saúde técnica. Agora, mais do que nunca, neste período de domínio do espontâneo, do falso e primário espontâneo técnico em que vivem quase todos os nossos artistas, teríamos que buscar em Machado de Assis aquela necessidade, pela qual todos os grandes técnicos são exatamente forças morais. ${ }^{18}$

\footnotetext{
${ }^{17}$ ANDRADE, Aspectos da literatura brasileira, op. cit., p.89-108.

${ }^{18}$ Ibidem, p.95.
} 
Observa-se que não há mais fusão entre o "artista”, conhecedor do seu métier e mestre no artefazer, e o "intelectual": integram-se conceitos gerais, como "indivíduo" e "ser social", sem que, todavia, se confunda estes com aqueles. Essa distinção é mais um passo na tentativa de se resolver a contradição existente entre "liberdade criadora" e "engajamento": aqui, o que se vê é a valorização do exímio artista que foi Machado de Assis, apesar de sua postura intelectual muitas vezes questionável ("foi intelectualmente o antiproletário, no sentido em que principalmente hoje concebemos o intelectual”). Seu valor repousa no fato de que ele "tinha no mais alto grau uma técnica e bem definida sua personalidade intelectual", o que lhe tornou possível criar obras-primas. Quanto ao homem, esse "não combateu nada, não ultrapassou nenhum limite infecundo. Viveu moral e espiritualmente escanchado na burguesice do seu funcionarismo garantido". "Mas", continua Mário, "as obras valem mais que os homens", e a qualidade das obras de Machado, diferentemente do caráter de seu criador, é inquestionável: "Ele foi um homem que me desagrada e que eu não desejaria para o meu convívio. Mas produziu uma obra do mais alto valor artístico, prazer estético de magnífica intensidade que me apaixona e que cultuo sem cessar”.

O objetivo de Mário de Andrade é claro: valorizar ao máximo a qualidade artística da obra machadiana, fruto da excelência do seu artesanato, não da escolha dos temas nela retratados. Num momento crítico da história (no plano internacional, estava-se às vésperas da eclosão da Segunda Grande Guerra, e, na esfera nacional, estávamos sob o jugo do Estado Novo getulista desde 1937), no qual o engajamento do artista e do intelectual se fazia tão necessário, a própria ideia de arte corria o sério de risco de esvaecer-se. Mário tenta mostrar que o engajamento, para o artista (distinguindo-o, portanto, do intelectual), pode e deve realizar-se no plano da obra (essa superior àquele), e que o esforço de inalienação do artista realizar-se-ia mediante uma "postura estética" diante da realidade. Há, entretanto, algo que parece contraditório: sendo o indivíduo Machado de Assis o que foi, isto é, um cidadão alienado de sua realidade social (segundo Mário, evidentemente), como seria possível que sua arte resultasse do perfeito equilíbrio entre "artesanato", "virtuosidade" e "consciência artística"? Não teria faltado ao escritor carioca aquela "postura estética" diante da realidade tão necessária ao artista para que ele torne grande a sua obra? Sem essa qualidade, a obra de Machado não seria apenas o resultado de um grande virtuosismo, elaborada por um grande artesão, conhecedor de seu material de trabalho? Por mais importantes que sejam o "artesanato" e a "virtuosidade" (e eles o são), parece, entretanto, impossível crer que Machado de Assis represente, nos termos propostos em "O artista e o artesão", um modelo de artista a ser seguido pelos moços. Contradições como essa mostram que o impasse que se vem percorrendo desde o início da década de 1930 ainda não encontrou uma solução satisfatória.

"Belo, forte, jovem"19, publicado em 1939, é uma análise dos Novos poemas de Vinícius de Moraes, lançados no ano anterior. A base teórica que sustenta esse texto tem sua origem no artigo "O artista e o artesão": as análises de Mário têm por pilar o exame da qualidade técnica do artefazer do poeta carioca, dos seus conhecimentos do artesanato poético, de sua escolha temática e, sobretudo, de sua atitude crítica perante a realidade. Veja-se esta passagem:

O que há de admirável no poeta é justamente, em plena mocidade, ter conseguido autocrítica bastante pra reconhecer o descaminhamento, ou melhor, o perigo em que estava, e tentar se enriquecer de mais profunda, mais humana, mais pessoal realidade. Estes Novos poemas são assim um esforço muito perceptível do poeta pra se justificar mais alargadamente. Nada mais daquela tese de estandarte, que valia, ou procurava valer muito mais para beleza de suas cores que pela ação da própria poesia.

${ }_{19}$ ANDRADE, Mário de. O empalhador de passarinho. 3a edição. São Paulo: Martins Editora; Brasília, INL/MEC, 1972, p. 15-21. 
O desejo de Vinícius de alcançar a "poesia altíssima” é apontado por Mário de Andrade como um grande risco, detectado a tempo pelo poeta carioca: a beleza, principal qualidade dos Novos poemas, viria justamente do fato de que a obra representa (como realização concreta, no nível da forma) o esforço do artista em integrar sua poesia à realidade circundante, ou a realidade circundante à sua obra poética. Em outras palavras, os Novos poemas seriam o resultado da atitude do poeta diante de sua realidade, o que por si só não justificaria sua beleza, mas estabeleceria seu valor como instrumento de ação. A beleza resultaria da competência técnica do poeta, ideia que é, aliás, diversas vezes ressaltada nesse artigo: ao contrário de outros novos poetas, "mocidade apressadíssima e desleixada", "rapaziada ignorantíssima da arte e da linguagem", Vinícius destaca-se como um "poeta que repôs o artesanato francamente como uma das necessidades da sua poesia atual".

E, imbuído de suas responsabilidades de "intelectual-instituição", Mário de Andrade não se furta a sinalizar erros futuros, sobretudo os relativos à escolha temática, à "busca do essencial": "Acho que o essencial, em poesia, não é o Amor, a Vida, Deus, e outras maiúsculas, mas a própria poesia, a indefinível poesia". É importante ressaltar que a crítica aos valores absolutos e que a preocupação em definir o que constituiria a essência da poesia não têm suas raízes apenas na apreciação e no julgamento da poética da nova geração de poetas que nascia no Brasil. Essa crítica insere-se num quadro mais amplo, internacional, e dialoga diretamente com outros textos e pontos de vista, dentre os quais, como se viu, se destaca o citado La trahison des clercs. No mais, ela confirma a afirmação feita pelo autor (três anos depois, na conferência no Itamarati), para quem a "atualização da inteligência artística brasileira”, um dos princípios e objetivos do movimento modernista, teria sido alcançada.

A poesia em pânico, obra de Murilo Mendes publicada em 1938, é analisada por Mário de Andrade em abril do ano seguinte. É significativo o fato de que Mário tenha dado a seu artigo ${ }^{20}$ o nome do livro analisado: A poesia em pânico seria o paradigma da situação na qual se encontrava a poesia brasileira naquele momento. O enfoque da leitura é fundamentalmente estético, estendendo-se da análise da temática dos poemas ao exame dos procedimentos formais. A busca pelo essencial, para onde Murilo canalizaria todo seu trabalho de pesquisa estética - e que teria a religião como eixo em torno do qual circularia o campo temático do poeta -, é apontada como um dos aspectos responsáveis pelo resultado final da obra de Murilo. Essa busca seria discutível, pois desviaria a atenção do poeta de outro elemento fundamental do fazer artístico: o artesanato, como revelam as passagens seguintes: "[O livro] se apresenta cheio de pequenas falhas técnicas, provando despreocupação pelo artesanato", "Os elementos da perfeição técnica, os encantos da beleza formal estão muito abandonados. O verso-livre é correto, mas monótono, cortado exclusivamente pelas pausas das frases e ideias", "O ritmo é bastante pobre".

O propósito de Mário é mostrar, à luz dos preceitos expostos em "O artista e o artesão" e a partir do caráter emblemático que assume o livro de Murilo Mendes, que a obra de arte tem suas especificidades, que compreendem a qualidade técnica da criação e as soluções adotadas pelo artista na concepção de seu trabalho (derivadas de sua atitude estética diante da sociedade), e esses atributos asseguram à obra sua supremacia em relação ao artista.

"A volta do condor"21, escrito entre os anos de 1940 e 1941, é um longo estudo sobre as poéticas de Augusto Frederico Schmidt e Alphonsus de Guimaraens Filho. Mário de Andrade retoma e aprofunda, aqui, críticas que havia feito ao autor de Canto do brasileiro em "A poesia em 1930". Mário entende a poética de Schmidt como uma reação à poética modernista: o individualismo "antimoderno" de Schmidt opunha-se ao individualismo e às "personalidades irredutíveis" daqueles que nasceram com o movimento

\footnotetext{
${ }^{20}$ Ibidem, p.45-52.

${ }^{21}$ ANDRADE, Aspectos da literatura brasileira, op. cit., p.141-171.
} 
modernista, como Carlos Drummond de Andrade. No entanto, embora "tenha descido à rua" em defesa de valores nos quais acreditava (no caso, o catolicismo), Schmidt não fez de sua poesia uma "cantadora pragmática dos interesses sociais"; pelo contrário, em sua temática sobressai a defesa dos Valores (com inicial maiúscula) universais (Deus, a Morte, a Amada...). Para Mário, Schmidt seria um autêntico "clérigo moderno", o que, todavia, não determina a priori a qualidade de sua obra: essa só pode ser inferida a partir da análise do "individualismo de Augusto Frederico Schmidt, [d]aquilo em que ele solucionou numa forma, isto é, em poesia, [d] as suas idiossincrasias e tendências pessoais", ou seja, a partir do estudo da "solução pessoal" do poeta. O que se segue, então, é uma análise da composição de seus poemas, nos quais se destaca a repetição de imagens-símbolos, comprovando a tese de que esse "poeta [seria] pouco preocupado de perfeição artística".

A parte subsequente do ensaio é dedicada a Alphonsus de Guimaraens Filho, cuja poética seria marcada pelos mesmos defeitos de composição que Mário tanto criticara em Schmidt. A aversão ao trabalho formal e a redução da imagística do poeta a um pequeno número de imagens-símbolos (de fundo europeu, para piorar...) eram os pontos que mais preocupavam o ensaísta, pois despontavam como tendências da nova poesia brasileira. E Mário, cuja noção de responsabilidade para com os mais novos era enorme, não poderia deixar de anotar esses perigos, exercendo a crítica literária com muito rigor.

No final do ensaio, o autor realça o perigo que representa para a nova poesia brasileira a adoção de uma temática extremamente elevada ("trigésimo andar"), em oposição ao nível "rés-do-chão" em que se situava a poesia anterior, porque "essa macaqueação do profundo, do essencial [e] do eterno" traria em seu bojo a perda de contato com a realidade. Criticando a poesia condoreira, Mário retoma os preceitos propostos em "O artista e o artesão": não seriam justamente o desprezo pelo artesanato e a falta de atitude estética diante da vida os erros mais graves que cometiam os nossos novos poetas?

Se se confrontarem os escritos do início da década de 1930 com os artigos do final da década, observar-se-á uma evolução no pensamento de Mário de Andrade no que tange à busca de resolução para as indefinições e incoerências que se estabeleceram nos textos iniciais: o impasse que se configurava naquele instante advinha da incapacidade de Mário de determinar - e distinguir - a função e os atributos do artista (e da obra de arte) e do intelectual, no momento em que, conforme indica Lafetá, o movimento modernista muda de perspectiva e o aspecto ideológico sobrepuja o estético. A resolução desse impasse, entretanto, não alcança êxito, conforme a leitura dos textos do final da década permite constatar: sua dissolução é aparente, na medida em que a questão do intelectual não é resolvida, mas apenas posta de lado em benefício da discussão referente ao papel do artista e da obra de arte. Observa-se, desse modo, o retorno do aspecto estético ao primeiro plano das inquietações mariodeandradianas. Os motivos pelos quais isso ocorre parecem difíceis de apontar, mas creio que o desencanto com os rumos políticos do país (o Estado Novo alcançava o apogeu), as experiências políticas (em que sobressai seu afastamento do Departamento de Cultura de São Paulo em 1937) e as novas tendências da poesia brasileira (que punham em risco as árduas conquistas do movimento modernista) exerceram um papel decisivo nas formulações de Mário de Andrade.

E assim chega-se ao fim e ao cabo destas reflexões: como dito no início, tencionou-se fornecer subsídios para a leitura dos "grandes textos" de Mário de Andrade escritos nos anos 1940, dos quais se destacam "A elegia de abril", "O movimento modernista" e a entrevista "A arte tem de servir", concedida a Francisco de Assis Barbosa. Esses textos, "interessados”, têm sido diversamente interpretados por aqueles que, reconhecendo sua importância para a historiografia da cultura brasileira, se propõem a examiná-los. A meu ver, alguns dos equívocos cometidos pela crítica não teriam lugar se os textos da década de trinta 
fossem mais bem conhecidos: eles revelam-se, como assinalado desde o início, menos "contaminados" pelas "condições absolutamente anormais da vida"22 que a humanidade vivenciou ao longo da década de quarenta (e que, no mais, perduram até os dias de hoje...).

Mário não sobreviveu aos desdobramentos do pós-guerra, cujos tentáculos abarcaram todos os domínios da atividade humana, inclusive a arte. Seus últimos textos exigiriam uma análise mais minuciosa. Arriscaria, entretanto, lançar uma questão que julgo pertinente: tendo o modernismo alcançado um de seus maiores objetivos, a saber, a "atualização da inteligência brasileira", e sendo Mário de Andrade um profundo conhecedor da cultura francesa, parece verossímil supor que ele seria um dos primeiros de nossa intelligentzia a dialogar com as grandes ideias que despontam naquele período e que têm como centro a questão do artista e do intelectual no mundo moderno. Dentre essas ideias, destacam-se as propostas lançadas por Sartre em Qu'est-ce que la littérature?(1948) ${ }^{23}$, obra na qual o escritor francês prega o engajamento do artista e do intelectual modernos (não fazendo distinção entre um e outro), mas determina um lugar especial para a poesia: o poeta, diferentemente do escritor de prosa (cuja arte se exerce no nível do discurso), é "hors du langage", o que lhe confere uma função social e artística especial: exigir seu engajamento seria tolice, seria ignorar o caráter próprio e específico da poesia. As concepções sartrianas relativas ao papel do intelectual e do artista lembram, em muitos aspectos, as reflexões mariodeandradianas. A aproximação desses dois grandes pensadores parece-me importante e pode trazer novas ideias aos que se interessam não somente pela questão que norteou este trabalho, mas também a todos os estudiosos das obras de Mário e de Sartre.

Recebido em: 02/10/2015. Aprovado em: 15/01/2016

\footnotetext{
${ }^{22}$ LOPEZ, Telê Porto Ancona. “'A arte tem de servir': transcrição de uma entrevista de Mário de Andrade”. In: Almanaque Cadernos de Literatura e Ensaio. São Paulo, Brasiliense, n.8, 1979, p. 39. Entrevista concedida a Francisco de Assis Barbosa e publicada originalmente na revista Diretrizes, São Paulo, 6 jan. 1944.

${ }^{23}$ SARTRE, Jean-Paul. Qu'est-ce que la littérature? Paris: Gallimard, 1981.
} 